\title{
Geological conditions of geothermal resource occurrences in Poland
}

\author{
Anna SOWIŻDŻAŁ ${ }^{1, *}$, Wojciech GÓRECKI ${ }^{1}$ and Marek HAJTO ${ }^{1}$ \\ 1 AGH University of Science and Technology, Faculty of Geology, Geophysics and Environmental Protection, Department \\ of Fossil Fuels, al. A. Mickiewicza 30, 30-059 Kraków, Poland
}

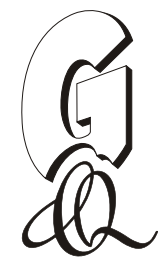

Sowiżdżał, A., Górecki, W., Hajto, M., 2020. Geological conditions of geothermal resource occurrences in Poland. Geological Quarterly, 64 (1): 185-196, doi: 10.7306/gq.1526

Associate Editor: Szymon Uścinowicz

The occurrence of geothermal resources in Poland relates to four main hydrogeothermal provinces: the Polish Lowlands, the Carpathians, the Carpathian Foredeep and the Sudetes, each characterized by different geological conditions. Recognition of Poland's geothermal potential on a regional scale is good, yet, in order to evaluate the capabilities of utilising geothermal waters taking into account specific local conditions, a detailed geological, hydrogeological and thermal analysis is required in each case. Sometimes, the results of this analysis provide new insights into the geological structure and hydrogeological conditions in the region of specific resources, and indicate alternative approaches to resource evaluation. We summarise the geological conditions around geothermal water resources in Poland, and also illustrate local variability in selected hydrogeothermal parameters in the area of Wiśniowa, located in the Outer Carpathians, and in Poddębice, a central part of the Polish Lowlands. Selected examples of the effects of the research carried out in these areas of Wiśniowa and Poddębice show situations where the results of making a borehole can be unpredictable.

Key words: geothermal energy, geothermal resources, Wiśniowa, Poddębice, Poland.

\section{INTRODUCTION}

Geothermal waters are a source of clean and ecological renewable energy, the effective management of which brings a number of benefits: environmental, economic and social. They are part of the natural riches of a given region. A large advantage is the possibility of using geothermal waters for various purposes: from heating to balneotherapy and recreation and other purposes. A key sector of geothermal energy management in Poland is heating; work is in progress in Poland on the possibility of managing existing low-temperature geothermal energy resources in order to produce electricity. A wide range of geothermal waters and energy applications means that areas using this kind of renewable energy become attractive to tourists. This also relates to air quality improvement caused by geothermal resources management for energy-producing purposes. However, geothermal resources are distributed unevenly and not every area is characterized by prospective geothermal potential. The economic effectiveness of geothermal investments is influenced by many factors. The most important issues are related to hydrogeothermal conditions prevailing locally, particularly as regards the discharge and the wellhead

\footnotetext{
* Corresponding author, e-mail: ansow@agh.edu.pl
}

Received: February 6, 2019; accepted: January 9, 2020; first published online: April 7, 2020 temperature of the exploited water. Only stable discharge and a sufficient wellhead temperature combined with relatively low Total Dissolved Solids (TDS) may guarantee the successful life of geothermal project. An important geological parameter influencing the economic viability of geothermal installations is the depth to the groundwater horizon, which affects geothermal parameters, e.g. water temperature, but also the costs of deep drilling.

Due to the location of natural resources in the subsurface, there is an appreciable amount of risk and uncertainty associated with exploration for such resources whether they are petroleum, mineral, groundwater or geothermal. There is a strong need in the geothermal sector to reduce risk and uncertainty, especially during the exploration stage (Witter et al., 2019).

Geothermal studies conducted in Poland since the 1980s have enabled good regional assessment of Poland's geothermal potential. An important contribution here were the Geothermal Atlases published from the 1990's until 2013 (Górecki et al., $2015 b$ ), which enabled recognition of the geothermal potential of $\sim 90 \%$ of Poland: the Polish Lowlands, the Carpathians and the Carpathian Foredeep. Despite information on the occurrence of geothermal waters in the Sudetes region dating to the twelfth century, it deals with point sources, and the Sudetes area has not yet received monographic treatment. In seven places, thermal waters have been found that issue from the granites and gneisses of the crystalline substrate. Published monographic atlases are an effective form of mapping the occurrence of geothermal waters in different Polish regions and a basis for preparing further local studies of promising areas at the local scale. 
The unpredictability of hydrogeological and geothermal parameters in various regions of Poland is indicated by research of the AGH University of Science and Technology regarding the geothermal potential around Wiśniowa and Poddębice. The Wiśniowa area is located in the Outer (flysch) Carpathians, regionally characterized by a low geothermal potential, stemming from a particularly low potential of water output over most of the area (Górecki et al., 2013, 2015a). The complex geological structure of this region makes it additionally difficult to designate hydrogeothermal parameters. Geological documentation of the Wiśniowa 1 borehole geological documentation inspired closer analysis of the possibilities geothermal energy utilisation in this area. During drilling (in 1990-1991) brine with an output of $180 \mathrm{~m}^{3} / \mathrm{h}$ at $85^{\circ} \mathrm{C}$ started to outflow spontaneously and abruptly.

Such water parameters point to the possibility of wider management. In turn, in the area of Poddębice, a geothermal heat plant has been in operation since 2010 , which produces fresh waters with low mineralisation $(0.4 \mathrm{~g} / \mathrm{L})$. While designing Poddębice GT-2 borehole, there were no premises to specify such low water mineralization, particularly because little more than 10 kilometres away, a geothermal plant operates in Uniejów, where water with mineralisation of $\sim 6-8 \mathrm{~g} / \mathrm{L}$ has been produced for 20 years.

\section{GEOLOGICAL BACKGROUND OF GEOTHERMAL WATER RESOURCE LOCATIONS IN POLAND}

Poland is characterized by low-temperature geothermal resources, defined as heat obtained from the geothermal fluid in the ground at temperatures of $150^{\circ} \mathrm{C}$ or less. These kinds of geothermal resources are typically for direct-use applications, such as district heating, greenhouses, balneotheraphy etc. Geothermal resources are strictly geologically determined. Poland is situated at the interface between three main European geostructural units (EGS): the Precambrian East European Platform, the Paleozoic units of Central and Western Europe (Caledonian and Variscan) and the Carpathian range (part of the Alpine system). Each of these structures is characterized by distinct geothermal conditions. Sedimentary rocks cover almost the whole territory of Poland, the main exception being the Sudetes Mts., where mostly crystalline and metamorphic rocks occur. Geothermal energy in Poland is accumulated in four geothermal provinces: the Polish Lowlands, the Carpathians, the Carpathian Foredeep and the Sudetes Region. Each of these provinces is characterized by different geological conditions and different geothermal water parameters.

One of the most prospective regions for geothermal energy development in Poland is connected with the Polish Lowlands. Water in these areas is characterized by favourable temperatures (reaching $>90^{\circ} \mathrm{C}$ ) and favourable values of well discharges (to several hundred $\mathrm{m}^{3} / \mathrm{h}$ ). The principal resources of geothermal waters in the Polish Lowlands are present in Mesozoic rocks. Geothermal waters have accumulated primarily in Lower Jurassic and Lower Cretaceous strata (Górecki et al., 2015b). The Polish Lowlands also is one of the most prospective areas for geothermal energy utilization in an Enhanced Geothermal System (Sowiżdżał et al., 2013; Sowiżdżał, 2016, 2018). Reservoirs favourable for EGS, Carboniferous and Lower Triassic sandstones, are located in the central part of Poland (the Mogilno-Łódź Trough region and small parts of the Kujawy Swell and Fore-Sudetic regions).

In the Carpathian Foredeep, aquifers of the Cenomanian, Upper Jurassic, Devonian-Carboniferous and Miocene are most prospective. However, in these aquifers, the most favour- able parameters for the location of geothermal intakes occur in small areas and narrow depth intervals. The Cenomanian aquifer is an exception, as high discharges (to $250 \mathrm{~m}^{3} / \mathrm{h}$ ) can be expected over the whole area of its occurrence (the central part of the Carpathian Foredeep). Zones with increased potential well discharges are sporadically encountered in the Upper Jurassic (tens $\mathrm{m}^{3} / \mathrm{h}$ ) and in the Miocene aquifers $\left(>100 \mathrm{~m}^{3} / \mathrm{h}\right.$ ). The best hydrogeological and geothermal parameters, that indicate the possibility of using the Miocene-hosted geothermal water, occur in the depth interval 500-1500 m b.s.l. The remaining depth intervals seem of low prospectivity because of low temperatures or weak hydrogeological parameters that determine low discharges at geothermal water intakes (Górecki et al., 2012).

In the Carpathians the best reservoir and exploitation properties for geothermal water utilization occur in the Inner Carpathian - Podhale Region, represented by: favourable reservoir parameters and lithology, usually high yields, and a regional extent of the aquifer, as well as recent recharge and low TDS. Podhale is a region in the Western Carpathians where geothermal waters have been utilized recently and will be utilized in the future, mostly for heat generation but also for recreation and balneotherapy. The reservoir rocks for the geothermal waters are mainly Triassic carbonates, and locally Jurassic sandstones and carbonates. The most prospective aquifer occurs within Middle Triassic limestones and dolomites and in overlying Middle Eocene carbonates at depths of 1-3.7 km (Hajto, 2011). In the remaining parts of the Carpathians, reservoir parameters are much worse. Geothermal aquifers in the Outer Carpathians are characterized by usually small and non-renewable resources as well as by high mineralization, which excludes their wider use. These waters occur usually in small closed structures, which restricts the possibility of higher outflows (Chowaniec, 2009).

Quite different geothermal conditions are present in the Sudetic Geothermal Region. This region in SW Poland, including the Sudetes Mts. and the Fore-Sudetic Block and limited to the NE by the Odra Fault, contrasts with the rest of Poland's geological setting. Instead of large sedimentary basins of the Polish Lowlands and the Carpathian foredeep or folded flysch strata of the external Carpathians, the Sudetes Mts. consist mainly of old crystalline rocks overlain by younger deposits. Precambrian and Lower Paleozoic gneisses and schists with scattered marble intercalations are intruded by Upper Carboniferous granitoids which form structures such as the core of the Karkonosze-Izera Massif. In synclinal structures the crystalline rocks are overlain by Phanerozoic strata (Silurian-Quaternary). Geothermal waters occur in this region only within the crystalline rocks. Most of the limited hydrogeothermal investigations carried out so far in the Polish part of the Sudetes were restricted to zones of occurrence of thermal waters utilized for therapeutic purposes, or to a few areas in which prospection has been carried out for such waters (Fistek, 1989; Dowgiałło, 2002; Ciężkowski, 2011). However, the Sudetic region is characterized by favourable thermal conditions. In Cieplice, water at $86.7^{\circ} \mathrm{C}$ was obtained from $2002.5 \mathrm{~m}$ depth. For this reason, the Cieplice area in the Sudetic geothermal region has been studied to identify a prospective location for the HDR project in Poland (Wójcicki et al., 2013) as well as to identify an appropriate location for binary systems (Bujakowski et al., 2014).

The occurrence of geothermal resources depends regionally on geological conditions. In Poland, we can distinguish four regions characterized with different hydrogeothermal conditions (Table 1). The highest geothermal potential relates to the Polish Lowlands and Podhale area, being a part of the Carpathians (Fig. 1). Much lower perspectives relate to the area of the Carpathian Foredeep (due to low well outflows) and the 
Predicted geothermal parameters in various regions of Poland

\begin{tabular}{|c|c|c|c|c|}
\hline & Polish Lowlands & Carpathian Foredeep & Carpathians & Sudetes \\
\hline Geothermal reservoir & sedimentary & sedimentary & sedimentary & crystalline, metamorphic \\
\hline Temperature $\left[{ }^{\circ} \mathrm{C}\right]$ & $30-130$ & $20-120$ & $20-120$ & $\max .86 .7$ \\
\hline Discharge of wells $\left[\mathrm{m}^{3} / \mathrm{h}\right]$ & $\begin{array}{l}\text { high, locally reaching } \\
>300\end{array}$ & $\begin{array}{c}\text { usually }<20, \text { the excep- } \\
\text { tion being the } \\
\text { Cenomanian aquifer - } \\
\text { max. } \sim 250\end{array}$ & $\begin{array}{c}\text { from low in Outer } \\
\text { Carpathians to up to } 550 \\
\text { (Inner Carpathians - } \\
\text { Podhale) }\end{array}$ & $\begin{array}{c}\text { from several to several } \\
\text { tens }\end{array}$ \\
\hline $\begin{array}{l}\text { Water mineralization } \\
{[\mathrm{g} / \mathrm{L}]}\end{array}$ & $\begin{array}{l}\text { varied, locally high, lo- } \\
\text { cally exceeding } 300\end{array}$ & $\begin{array}{l}\text { varied, locally high, in } \\
\text { places exceeding } 300\end{array}$ & from several to 120 & to $\sim 10$ \\
\hline Perspective areas & Mid-Polish Trough & central part & Podhale & Cieplice and other \\
\hline
\end{tabular}

remaining part of the Carpathians. In the Sudetes, geothermal waters occur in patches, and geothermal reservoirs, unlike in other regions, are built of crystalline rocks.

In 2018 the installed geothermal capacity of six geoDHs was 74.6 MW and geothermal heat production was 250.4 GWh, while total production amounted to $289.5 \mathrm{GWh}$. The oldest and largest geothermal heating plant in Poland is located in the Podhale Region (Fig. 1). The total maximum artesian water flow rate produced by 3 wells is $\sim 297 \mathrm{~L} / \mathrm{s}$ of $82-86^{\circ} \mathrm{C}$ water. In 2018 the installed geothermal capacity was $38.8 \mathrm{MW}$ (total $77.9 \mathrm{MW}$ ) while geothermal heat production amounted to $141.5 \mathrm{GWh}$ (509.5 TJ). 5 out of 6 operating geothermal heating plants in Poland are located in the Polish Lowlands: Pyrzyce (maximum geothermal water flow rate was $100 \mathrm{~L} / \mathrm{s}$ at $61^{\circ} \mathrm{C}$, installed capacity $22 \mathrm{MW}$, including $6 \mathrm{MW}$ geothermal), Mszczonów $\left(16.6 \mathrm{~L} / \mathrm{s}\right.$ at $42.5^{\circ} \mathrm{C}$, installed capacity $8.3 \mathrm{MW}$, including 2.7 MW absorption heat pump and $1 \mathrm{MW}$ compressor heat pump), Poddębice $\left(32.2 \mathrm{~L} / \mathrm{s}\right.$ at $71^{\circ} \mathrm{C}$, installed capacity $10 \mathrm{MW}$ geothermal capacity), Uniejów $\left(33.4 \mathrm{~L} / \mathrm{s}\right.$ at $68^{\circ} \mathrm{C}, 3.2 \mathrm{MW}$ geothermal capacity) and Stargard $\left(50 \mathrm{~L} / \mathrm{s}\right.$ at $87^{\circ} \mathrm{C}, 12.6 \mathrm{MW}$ geothermal capacity; Kępińska, 2019).

\section{METHODOLOGY OF STUDIES}

Studying the geothermal potential of a given area involves analysis of several fundamental hydrogeological and geothermal parameters. Knowledge of the general characteristics of the study area is necessary, together with analysis of available source materials, including borehole records. Geological conditions determine the existence of potential geothermal reservoirs. Identification of reservoirs is preceded each time by analysis of regional geological structure, and often the making of three-dimensional structural or structural-parametric models. The results of spatial modelling, based on analysis of available source materials (archival materials, as well as borehole, laboratory and geophysical data, including seismic data) reflect the structural system and lithological - reservoir variability of rocks making up the regional geological profile. At the Faculty of Geology, Geophysics and Environmental Protection, AGH University of Science and Technology, such modelling is performed using the Petrel program. A three-dimensional structural geological model of the area of Poddębice has been built on the basis of regional structural and thickness maps developed in the form of regular interpolation grids with $250 \times 250$ m spacing (2D grid). The structural model includes 5 stratigraphic units (Upper Triassic, Lower Jurassic, Middle Jurassic, Upper Jurassic, Lower Cretaceous). The static model procedure comprises the following (Dubrule, 2003):
- development of structural maps in the format of regular interpolation grids on the basis of seismic and borehole data and digital archival maps;

- creation of a 3D structural model, using RSI and interpretation of disjunctive tectonics;

- development of a fault model;

- development of a grid skeleton as a result of employing the pillar gridding procedure;

- creation of stratigraphic zones as a result of introducing stratigraphic surfaces to the model, and transformation into irregular 3D Horizon grids, where the mesh shape depends on the results of the pillar gridding procedure.

Another important aspect comprises the thermal characteristics of the area. Direct temperature measurements made in deep boreholes are a fundamental source of information about a depth heating regime. The quality of information on temperature distribution along the borehole profile, and hence, reliability, is closely related to technical conditions of making the measurements. The most useful method of obtaining thermal data in boreholes is the measuring/profiling of temperatures made in quasi-stationary conditions, i.e. after completion of drilling and with sufficient thermal stabilisation of the borehole, usually after 12-14 days (Plewa, 1994a, b).

In order to estimate water intake output, formulae of classical hydrogeology are used, which are also utilized in basic calculations of underground water filtration for inflow to a fully and partially penetrating well in set filtration conditions. Calculations of an inflow to a well involves the adoption of a calculation scheme, which usually introduces simplifications by comparison with actual conditions of underground water stream flow (Kulma, 1995). As regards steady-state filtration, the best known and commonly used is the Dupuit equation. It assumes the existence of a hydrological well with a small diameter, working with output and water table depression unchanging in time. An aquifer has an unconfined expansion, constant thickness and shows a permanent value of the filtration index. The water table before well pumping is disposed horizontally, while laminar movement of underground waters towards the hole can be treated as flat-radial (equipotential surfaces are sides of a cylinder). When analysing possibilities of utilising thermal waters at the current stage, the output of a water intake is not a fixed value, depending on a number of factors including the hydrogeological reservoir and exploitation parameters. The results of calculations of predicted water intake outputs closely depend on the parameters of well exploitation adopted, and firstly, the length and diameter of an exploitation filter and the assumed value of an exploitation depression. Sizes of exploitation outputs, with which an intake of deep groundwaters may work, should be determined by several stages of measuring of 


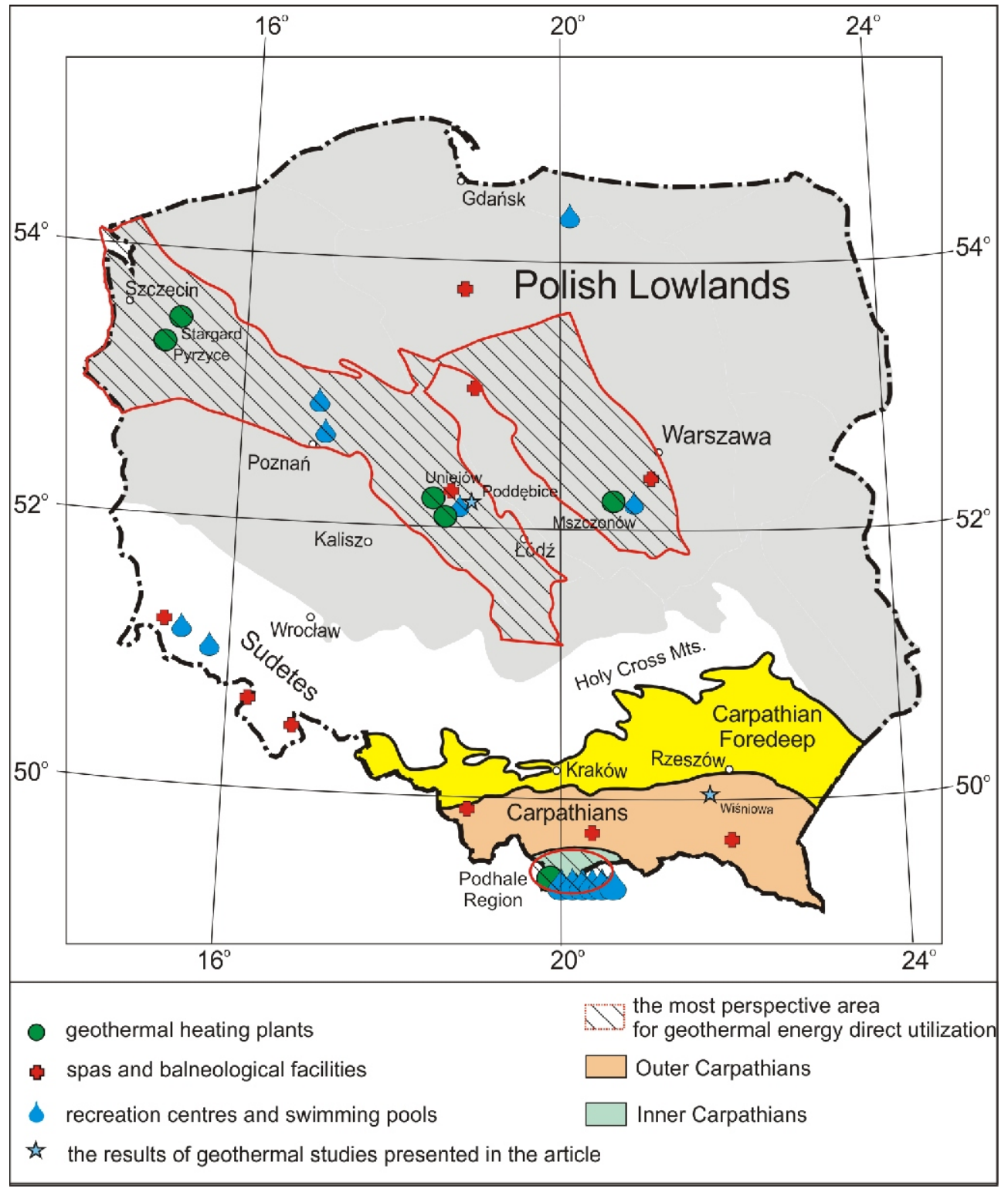

Fig. 1. The most prospective areas for geothermal energy utilization in Poland with the location of geothermal facilities

pumping and by the size of water resources, and by this means the size of operational expenses are subject to evaluation. The project is then approved and decided upon by a competent geological administration.

According to the modified form of Darcy's law for fixed radial flow, the efficiency equation (Dupuit-Thiem formula) takes the form:

$$
Q_{z}=2 \pi * k * m p * \frac{S}{\ln \frac{R}{r}}
$$

where: $Q$ - discharge of production borehole $\left[\mathrm{m}^{3} / \mathrm{s}\right] ; k$-hydraulic conductivity coefficient [m/s]; $m p$ - thickness of groundwater layer (limited by working length of screen) [m]; $S$ - permissible drawdown [m]; $r$ - radius of production filter [m]; $R$ - radius of depression cone [m]

Radius of depression cone was calculated using Sichardt's formula:

$$
R=3000 * S * \sqrt{k}
$$

where: $S$ - drawdown [m]; $k$ - hydraulic conductivity $[\mathrm{m} / \mathrm{s}]$.

To determine the possibilities of utilising geothermal waters, it is also necessary to analyse the chemical composition of water mineralisation. For utilising their thermal energy, groundwaters should have as low mineralisation as possible. The level of thermal water mineralisation and the specific constituents determine use for recreational and balneological purposes. Medicinal and geothermal waters differ in terms of their total dissolved constituents as well as in their kind and quantitative relations, and they also differ in terms of physico-chemical properties. Medicinal water is poorly mineralized, and it is currently required to document $<1000 \mathrm{mg}$ of dissolved solid constituents per $\mathrm{dm}^{3}$, including one or more specific medicinal constituents, at or above the concentrations listed in Table 2.

Mineral waters contain at least $1000 \mathrm{mg}$ of dissolved ingredients in $1 \mathrm{dm}^{3}$, including especially chlorides, sulphates as well 
Classification of specific water types (Journal of Laws, 605, 2006)

\begin{tabular}{|l|c|}
\hline \multicolumn{1}{|c|}{ Minimum content of constituents } & Water type \\
\hline $1 \mathrm{mg}$ iodides & iodide \\
\hline $1 \mathrm{mg}$ sulphides or other sulphur compounds & sulphurous \\
\hline $2 \mathrm{mg}$ fluorides & fluoride \\
\hline $10 \mathrm{mg}$ iron & ferrous \\
\hline $70 \mathrm{mg}$ metasilicic acid & silica \\
\hline $1000 \mathrm{mg}$ unbound carbon dioxide & "szczawa" \\
\hline $250-999 \mathrm{mg}$ unbound carbon dioxide & carbonic acid \\
\hline Temperature of at least $20^{\circ} \mathrm{C}$ at the outflow from an intake & thermal \\
\hline Radioactivity of at least $74 \mathrm{Bg} / \mathrm{dm}^{3}$ & radon \\
\hline
\end{tabular}

as sodium, calcium and magnesium bicarbonates, occurring in particular waters in different quantities.

The usefulness of geothermal waters for recreational or medicinal purposes is determined mainly by such parameters as temperature and water mineralisation. Conditions to be met in order for geothermal waters to be used for balneological and recreational baths include also water intake output, water pressure and depth of aquifer occurrence. In accordance with the requirements for waters used for bathing (Ponikowska, 1995, 2002; Ponikowska and Ferson, 2009), mineralisation of water used for recreational purposes cannot exceed $30 \mathrm{~g} / \mathrm{dm}^{3}$ (at temperatures of $24-30^{\circ} \mathrm{C}$ ), and for medicinal purposes: $50 \mathrm{~g} / \mathrm{dm}^{3}$ (at temperatures of $28-42^{\circ} \mathrm{C}$; Fig. 2). The higher water temperature and mineralisation allowed in medicinal pools compared with recreational pools reflects the fact that medicinal baths are more stimulating and have to be supervised by a physician, whereas recreational baths, due to the lack of such supervision, cannot be so stimulating.

The analytical results obtained are the basis for developing a geothermal water intake in a given region. Depending on the investor's needs and the geothermal water parameters obtained, water can be used for various purposes. A key sector in Poland is heating, though the concept of managing geothermal resources is used also for the construction of recreational or balneological centres based on geothermal waters. Utilisation of geothermal energy for heating purposes is determined mainly by such parameters as temperature and output, and here requirements for waters used for heating purposes are higher than in the case of waters used for recreational and balneological purposes (Fig. 3). Minimum output of geothermal water from an intake supplied to one recreational pool should range from 3 to $5 \mathrm{~m}^{3} / \mathrm{h}$ (Paczyński and Płochniewski, 1996). In using waters for heating purposes, output should be at least several tens of $\mathrm{m}^{3} / \mathrm{h}$.

In areas with abandoned oil wells, possibilities of well reconstruction can be assessed. The costs of drilling an exploratory or production borehole for geothermal waters are high and usually constitute $50-80 \%$ of funds allocated for the construction of a geothermal installation, including necessary surface infrastructure. In some cases, existing abandoned oil wells can be used, particularly as the costs of adapting them for geothermal purposes can be several times lower than the costs of drilling new wells. Wells designed for reconstruction should meet several technical criteria, stemming from the structure and technical condition of an abandoned well, which commonly is a long-term influence on aggressive conditions in the rock mass, causing e.g. corrosion of subsurface equipment in the well. Permeability of reservoir rocks in the vicinity of a well also deteriorates, in consequence of blocking of that zone with small particles, limiting inflow of reservoir waters to the well. In order to ameliorate damage to hydraulic conductivity, intensification processes are performed. Evaluating the construction of a well and its technical condition involves analysis of several parameters, including the method of well abandonment, the technical condition of the casing, the condition of cementation, the results of geophysical measurements, and so on.

Sometimes the construction of an oil well can make it impossible to adapt it into a geothermal borehole, and in such a case the costs spent on re-opening old oil wells can be comparable to the costs of drilling of a new borehole (Nian and Cheng,

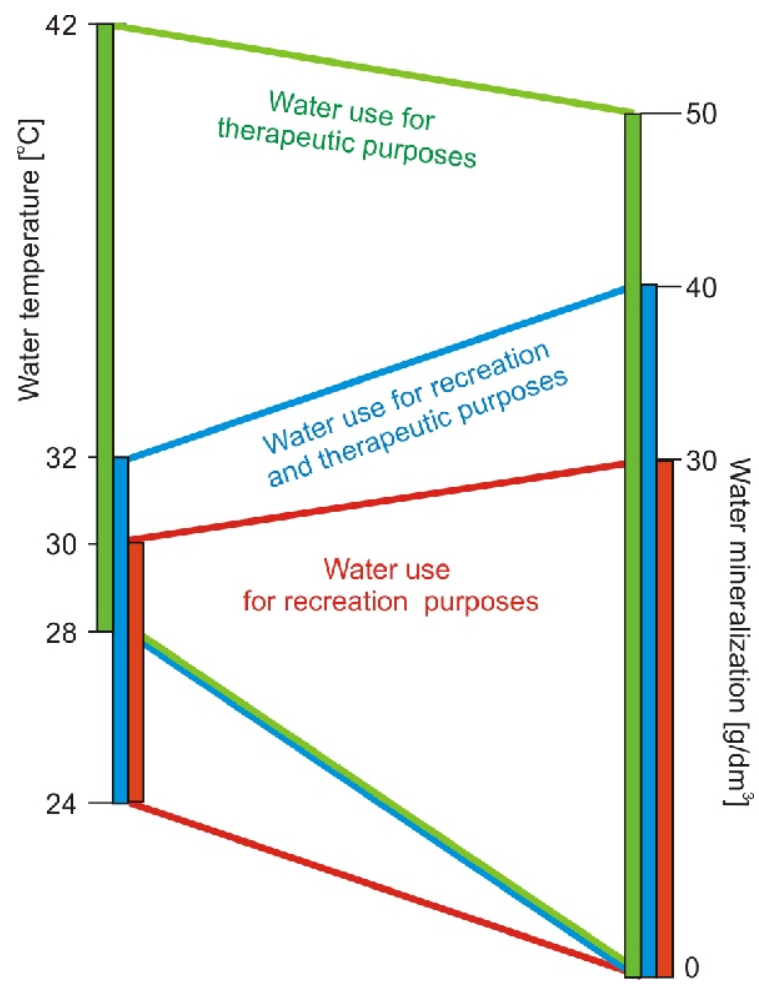

Fig. 2. Requirements for bathing water (Ponikowska and Ferson, 2009) 


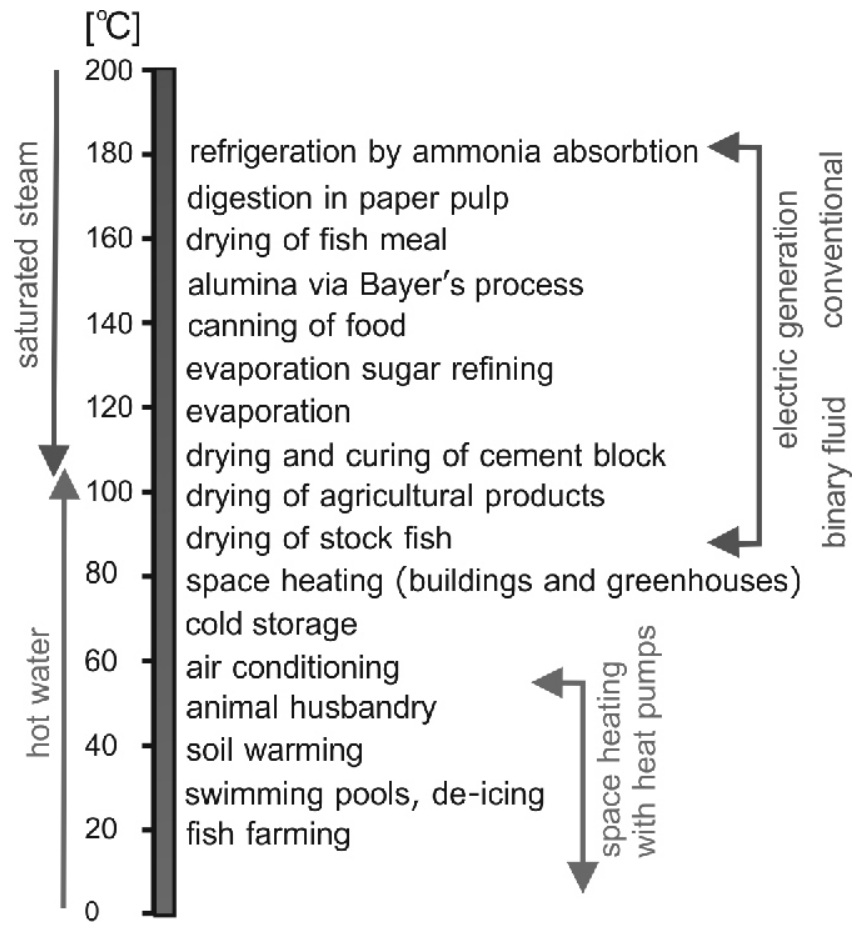

Fig. 3. Possibilities of thermal water utilization according to temperature criteria (Lindal, 1973)

2018; Westphal and Weijermars, 2018). Analysis of the technical possibilities and profitability of reconstructing each borehole is necessary.

\section{STUDY RESULTS}

\section{WIŚNIOWA - THE AREA OF THE CARPATHIANS}

The idea of utilising waters and geothermal energy in the area of Wiśniowa was inspired by the Wiśniowa 1 borehole, drilled in years 1990-1991, from which brine started to flow spontaneously and immediately, with parameters indicating the possibility of a wide range of applications. The well was originally drilled to prospect for hydrocarbons. Core samples showed no signs of hydrocarbons. However, spontaneous brine outflow was obtained in amounts of 5.2 up to $8.0 \mathrm{~m}^{3} / \mathrm{h}$ from $3698 \mathrm{~m}$ depth b.g.l., and in amounts of $180 \mathrm{~m}^{3} / \mathrm{h}$ at a temperature of $85^{\circ} \mathrm{C}$ from $3793 \mathrm{~m}$ depth b.g.l. After technical difficulties, such as a pressure increase up to 300 atmospheres and a brine outflow fracturing a pit embankment, the well was abandoned. At that time, no analysis was conducted with regard to managing waters made available by this borehole. Only after many years, on the initiative of local authorities, AGH University of Science and Technology researchers evaluated the possibilities of producing and utilising thermal waters in the Wiśniowa area (Górecki et al., 2015a).

Wiśniowa is located at the southern edge of Skole Nappe (Fig. 4), within the Strzyżowska Depression that is filled with folded Eocene-Oligocene strata. North of the Strzyżowska Depression, at the edge of the Skole Nappe there extends a zone of "Ropczyce Folds", comprising a thick succession of inoceramus beds, below which there are siliceous marls and older Cretaceous strata. South of the zone being analysed, the Skole Nappe lies beneath the Sub-Silesian and Silesian
Nappes (Oszczypko et al., 2008). Below the Skole Nappe, there are variable thicknesses of Zgłobice unit rocks, and below, autochthonous Miocene is locally recognized. A Mesozoic succession is formed mainly of Jurassic strata, and these underlain with Paleozoic rocks, whereas in a southern deep zone there are probably Mesopaleozoic and para-autochthonous flysch deposits (Fig. 4; Machowski et al., 2013).

Due to the complex geological structure, simply establishing the nature of a water-bearing unit caused problems. A potential water-bearing unit may be formed of Lower Cretaceous Spas shales, made up of fine-grained and compacted sandstones and hard marls and shales. The Spas shales are characterized by high plasticity, whereas sandstone reservoir levels are characterized by anomalous reservoir pressure gradients (Plezia, 1992). However, it seems more likely that the water which flowed spontaneously out of the Wiśniowa 1 borehole after the Spas shales were penetrated came from another reservoir, located at a lower level. Given the complex geological structure of the study area, underground waters may migrate, e.g. along fault zones. This premise, together with the poor reservoir parameters of the Spas shale sandstones, suggests Upper Jurassic carbonates, lying more deeply, as potentially prospective. Those formations, represented by marls and limestones, were drilled in the Szufnarowa 1 borehole (Oxfordian) at 4540-4697 m depth b.g.l. and in the Nawsie 1 borehole (Kimmeridgian + Oxfordian) in the interval 3098-4440 m b.g.l. The Lower Cretaceous reservoir may also be permanently supplied with waters from an Upper Jurassic reservoir as a result of hydraulic connection between them. In such a case, those reservoirs should be treated jointly (together with autochthonous Miocene strata).

The research led to three different scenarios of geothermal reservoir management, dependent upon the acquired hydrogeothermal reservoir parameters.

In an optimistic scenario, it is assumed that geothermal waters come from a pore-fracture reservoir built of Lower Cretaceous, Miocene and Upper Jurassic strata, remaining in hydraulic contact with one another. Waters in this reservoir are characterized by a temperature at the outflow of $\sim 85^{\circ} \mathrm{C}$ (over $90^{\circ} \mathrm{C}$ in the reservoir) and a high output of $\sim 180 \mathrm{~m}^{3} / \mathrm{h}$. Mineralisation of waters accumulated at this reservoir level reaches $\sim 15 \mathrm{~g} / \mathrm{dm}^{3}$. In this case, after conducting detailed physico-chemical analyses of the water one can consider the possibility of water dilution and its discharge to surface water courses (exploitation in a single-well system). However, in order to ensure reservoir renewal in the face of such high outputs $\left(180 \mathrm{~m}^{3} / \mathrm{h}\right)$, it is recommended to produce water in a double-well system (which makes it necessary to make an injection well).

A realistic scenario assumes that geothermal waters have accumulated in a fractured carbonate Upper Jurassic reservoir and are characterized with high temperature at the outflow of $\sim 125^{\circ} \mathrm{C}$, and output of $\sim 40 \mathrm{~m}^{3} / \mathrm{h}$ and mineralisation of $\sim 100 \mathrm{~g} / \mathrm{dm}^{3}$. Due to higher water mineralisation, it is necessary to utilise it by injecting it again into the rock mass with installation of an operation in a geothermal double system (1 production well and 1 injection well). Therefore, in both variants, it is necessary to plan an installation producing geothermal water with one production well and one injection well. In the pessimist scenario, Lower Cretaceous sandstones of Spas shales with poor reservoir parameters form the reservoir rock, which translates into a water intake output $<1 \mathrm{~m}^{3} / \mathrm{h}$. In this scenario, it is assumed that spontaneous outflow obtained when drilling the Wiśniowa 1 well in 1990s was temporary and after stabilisation of reservoir parameters, problems with water outflow will occur. 


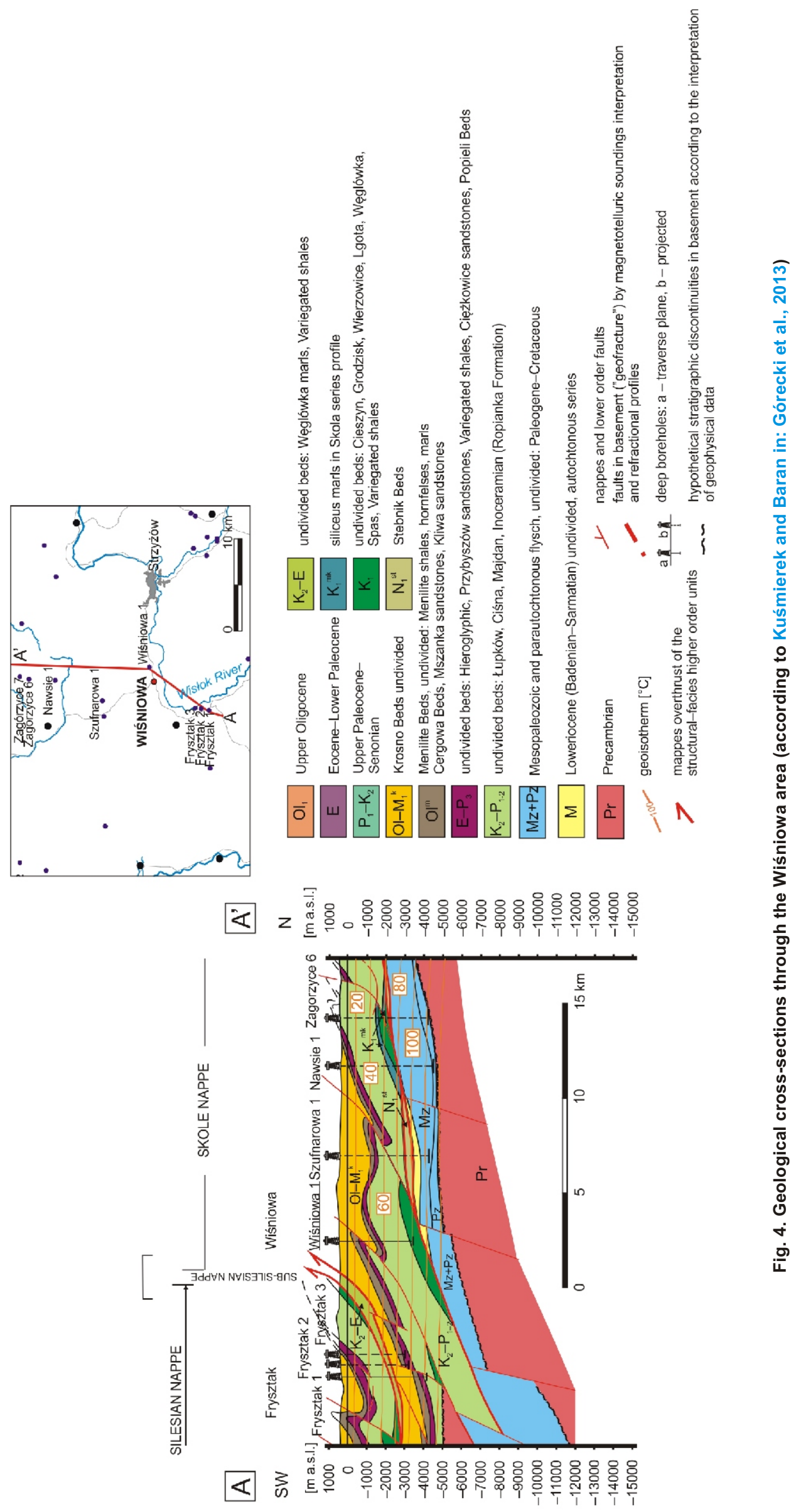




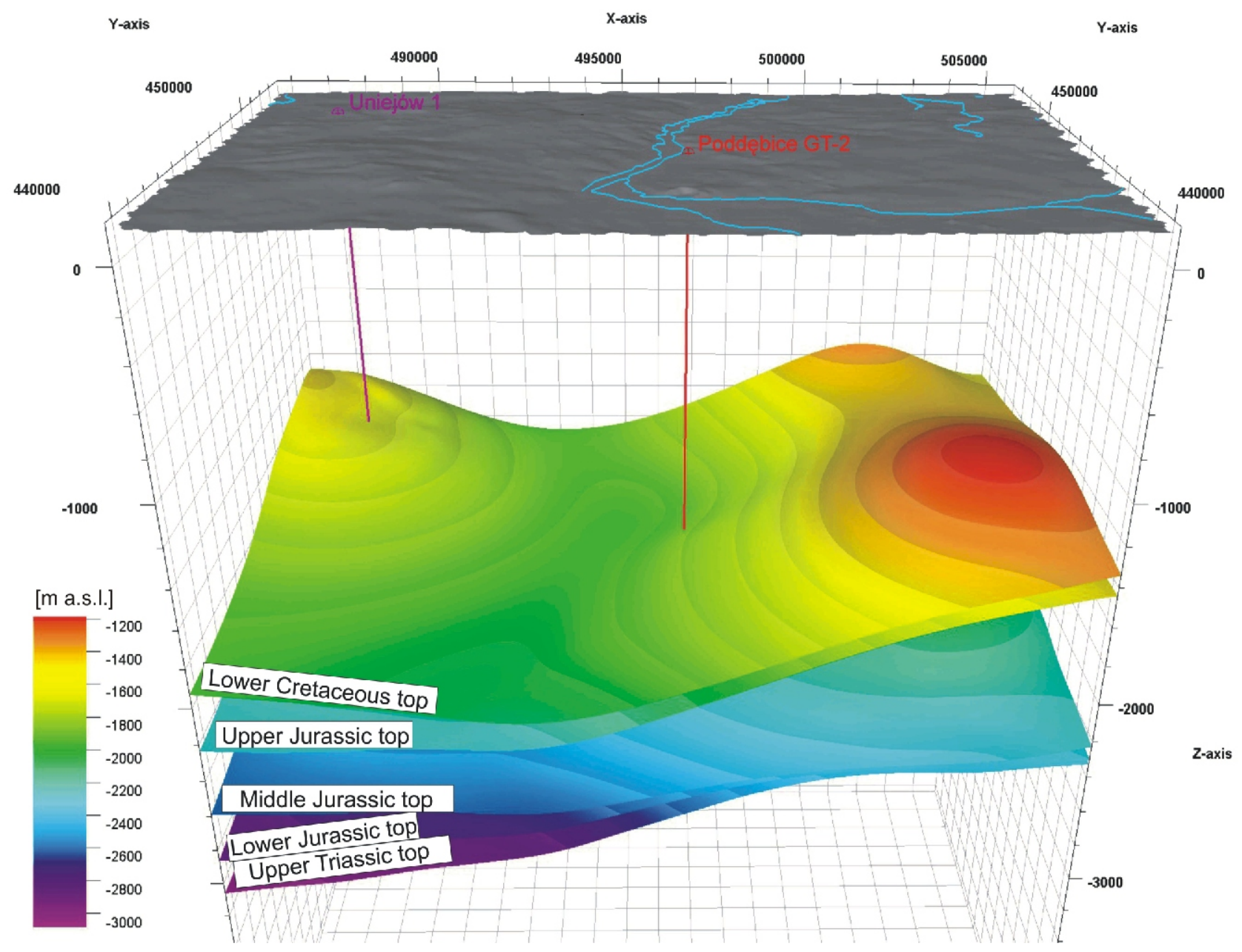

Fig. 5. Three-dimensional structural geological model of the Łódź Basin in the area of Poddębice

Location of 3D model shown on Figure 6

Despite the lack of water, the reservoir is characterized by a high temperature of $\sim 90^{\circ} \mathrm{C}$, such that one can consider utilisation of the energy potential by means of a borehole heat exchanger.

PODDĘBICE, IN THE POLISH LOWLANDS

The Poddębice GT-2 borehole is located in the central part of Permian-Mesozoic geological unit called the Mogilno-Łódź Trough, which is a part of a larger syncline - the Szczecin-Łódź-Miechów Trough. The geological structure of the Mogilno-Łódź Trough is complex, the effect of advanced salt tectonics (Wiktorowicz, 2014). This causes local discontinuities in geological successions, sudden changes in deposit thickness, especially in the area of anticlinal structures, which were formed during the Late Triassic and Late Cretaceous periods, as well as around the Cretaceous/Paleogene boundary, during the Laramide inversion (Dadlez et al., 2000). The anticlinal structures in the area of Poddębice were caused by salt tectonics, which were active during deposition of Mesozoic strata. A simplified 3D geological model of the Łódź Basin, with special emphasis on tectonic elements in the Lower Cretaceous rocks is shown in Figure 5. The shape of the Lower Cretaceous top is the result of local salt tectonics, when plastic salt strata, while moving upwards, created the forms of the Koło and Poddębice anticlines (Dadlez et al., 1994). The oldest strata recognized during drilling are fine-grained Lower Triassic sandstones and mudstones interbedded with limestones, overlying a Zechstein succession. The overburden comprises evaporitic and clastic Röt anhydrites, dolomites and mudstones. The Muschelkalk is developed in a pelitic limestone and marl facies. The Upper Triassic is made up of fine-grained sandstones interbedded with claystones. Muddy sandstones with rare mudstone interlayers are characteristic of the Triassic deposits in this area. The maximum Triassic thickness is $\sim 2000 \mathrm{~m}$. Above the Triassic, there are Lower Jurassic sandstones with claystone interbeds some $\sim 37 \mathrm{~m}$ thick. Dogger (Middle Jurassic) strata are represented mainly by dolomites and mudstones with thin glauconite sandstone interlayers. Upper Jurassic (Malmian) formations have thicknesses of up to $\sim 600 \mathrm{~m}$ and are mainly of carbonate facies, as limestones, marls, dolomites and mudstones, wih subordinate sandstones. The Lower Cretaceous commences with Hauterivian dark brown mudstones interbedded with claystones, $7 \mathrm{~m}$ thick, representing the shelf of environments (Tadych et al., 2010). The Hauterivian strata and Upper Jurassic marls constitute a natural seal between the Lower Cretaceous geothermal reservoir and the underlying Jurassic aquifer. Above the Hauterivian there are grey, fine- and medium-grained terrestrial sandstones of Albian, Aptian and Barremian age, which form a geothermal aquifer. The Upper Cretaceous comprises marls, creamy-grey limestones and argillaceous limestones with dark claystone interlayers. The 


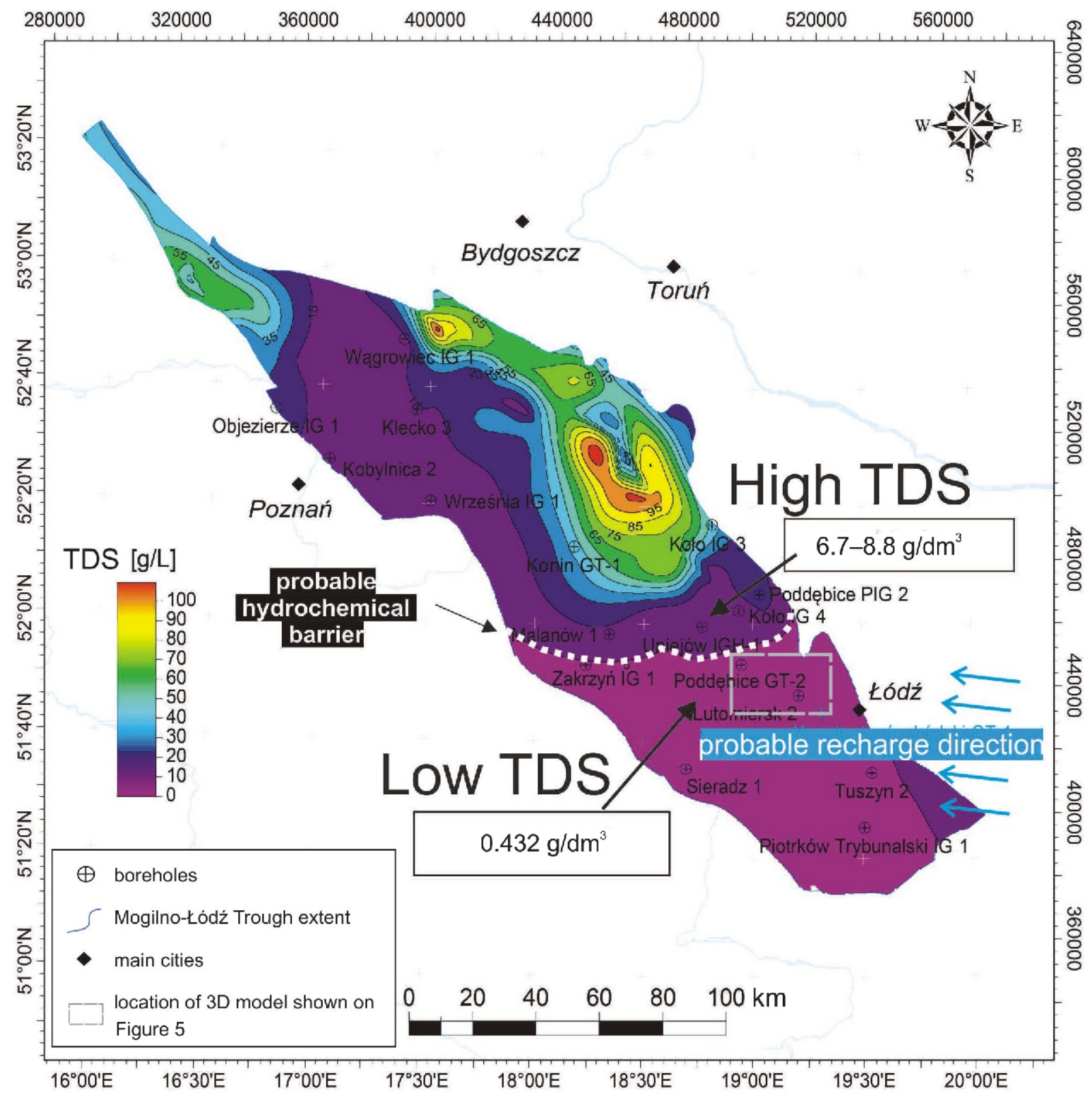

Fig. 6. Map of the TDS at the top surface of the Lower Cretaceous succession in the Mogilno-Łódź Trough (central part of Polish Lowlands)

Cenomanian is characteristically developed as limestones and cream-coloured marly limestones, similar to Upper Albian strata. The middle part of the Turonian formations is marl-claystone, whereas the upper part is argillaceous limestone, with flint interlayers. The Coniacian, Santonian and Campanian are represented by grey marly limestones and marls. Only the oldest Maastrichtian strata are preserved, younger ones having been eroded away. These are mainly marly limestones and mudstones in the overburden. At $10 \mathrm{~m}$ b.g.l. the Cretaceous succession comprises yellow medium-grained sand (Posyniak, 2015). In the area of the Poddębice GT-2 well, there are no Paleogene and Neogene deposits, because of glacial erosion, the intensity of which was magnified by epeirogenic movements. In the area of Poddębice, the main geothermal reservoir comprises fine-grained and, in places, medium-grained Lower Cretaceous sandstones, which are characterized by relatively high porosity.
The Poddębice GT-2 borehole was drilled in 2009/2010, reaching a depth of $2101 \mathrm{~m}$, at the top of the Upper Triassic. As artesian outflow of $116.5 \mathrm{~m}^{3} / \mathrm{h}$ of fresh geothermal water $\left(0.432 \mathrm{~g} / \mathrm{dm}^{3}\right)$ was obtained from Lower Cretaceous strata from 1957-2059 m b.g.l. (Tadych et al., 2010). The mineralization composition provided valuable information on TDS distribution at the top of the Lower Cretaceous in the Mogilno-Łódź Trough (Fig. 6).

Geothermal water in Poddębice is under artesian pressure - the static water table is at an altitude of $26 \mathrm{~m}$ a.g.I. Quartz constitutes $95 \%$ of the sandstones, with subordinate glauconite, feldspars and clay minerals, and they have a silica cement. The approved exploitation resources of Poddębice GT-2 well have been determined at $Q=252 \mathrm{~m}^{3} / \mathrm{h}$, with exploitation depression at the level of $85.3 \mathrm{~m}$ b.g.l. (Table 3). The geothermal water temperature measured at the outflow is $71^{\circ} \mathrm{C}$ (Tadych et al., 2010). The water is of exceptional quality, characterized by mi- 
Table of selected petrophysical-reservoir parameters of Lower Cretaceous strata relating to a geothermal water intake in the Poddębice GT-2 borehole (based on Tadych et al., 2010)

\begin{tabular}{|l|c|}
\hline \multicolumn{1}{|c|}{ Parameter } & Value \\
\hline Borehole depth & $2101 \mathrm{~m}$ \\
\hline Water type/mineralisation & $\mathrm{HCO}_{3}$-Na-Ca / 432 mg/L (considerable $\mathrm{SiO}_{2}$ content) \\
\hline Water temperature at outflow & $71^{\circ} \mathrm{C}$ \\
\hline Total thickness of Lower Cretaceous deposits & $108 \mathrm{~m}$ \\
\hline Aquifer & $1962-2063 \mathrm{~m}$ b.g.l. \\
\hline Aquifer thickness & $98 \mathrm{~m}$ \\
\hline Intergranular porosity (total) & $16-23 \%$ (no secondary porosity) \\
\hline Effective porosity & $13.7-17.0 \%$ (average: $16.2 \%)$ \\
\hline
\end{tabular}

crobiological purity and low mineralisation, which allows for it to be used directly, without any modifications, for rehabilitation treatment (Kępińska et al., 2017).

\section{DISCUSSION}

One of the inherent challenges of the geosciences is incomplete knowledge of the geological and hydraulic properties (geometries, temperature distribution, permeability, etc.) of the subsurface (Witter et al., 2019). In areas with complex geological structure or in places with scarce availability of geological information, determination of hydrogeothermal parameters is difficult. Commonly, interpretation of an area begins with the construction of a geological working model. Structural geology can play a key role in exploration for geothermal resources. As new input data is added, the modeling results are improved. This technique generates a geological interpretation of high uncertainty and results in working models that are inherently non-unique (Bond, 2015). The results obtained are constrained only after the geothermal reservoir has been accessed by boreholes. In some cases, the results of drilling a borehole can be unpredictable, as in the surprises encountered in the Poddębice and Wiśniowa regions.

Wiśniowa is located within the flysch Outer Carpathians, characterized by complex nappe-and-thrust geological structure, a situation that is difficult from the point of view of geothermal water management. Complex geological structure makes it difficult to specify hydrogeological conditions and the evaluation of the size and distribution of basic reservoir parameters, particularly in deeper intervals of the geology. Considerable lithological changeability of rocks, observed both horizontally and vertically, as well as the lack of a sufficient data make it impossible to define water circulation conditions, including the defininition of potential zones of deep groundwater reservoir supplies, their renewal, and the stability of forecasted outputs at geothermal water intakes over a longer period of time. These features seem to suggest a low geothermal potential of the region. But, there are indications (spontaneous brine outflows) which suggest that there may be significant geothermal resources in the region.

The analysis conducted near Wiśniowa does not give a clear answer with regard to the geothermal potential of the region. It indicates three different scenarios of geothermal reservoir management, dependent upon acquired hydrogeothermal reservoir parameters: optimistic, realistic and pessimistic. The area of Wiśniowa is a geothermal puzzle; this is why it belongs to a group of towns which received co-financing to make an exploratory borehole from the state budget. The results of such a borehole will constrain the hydrogeothermal parameters and legitimacy of the inferred solutions.

The results of the geothermal borehole in the Poddębice area were similarly unpredictable. Although Poddębice is located in a region with a less complicated geological structure than Wiśniowa, the results of the Poddębice GT-2 borehole came as a surprise. The occurrence at deep geological levels of waters with very low mineralization $0.432 \mathrm{~g} / \mathrm{dm}^{3}$ was an important outcome, which showed that in the central Polish region (Mogilno-Łódź Trough) no clear rules are observed in the vertical distribution of water mineralization, relative to the hydrochemical vertical gradient. Waters with the highest mineralisation $\left(>90 \mathrm{~g} / \mathrm{dm}^{3}\right)$ lie deepest, i.e. below $\sim 2000 \mathrm{~m}$, but at those depths one can also expect fresh waters, as confirmed by drilling of the Poddębice GT-2 borehole. The highest values of mineralisation most probably relate to salt structures and occur in the northeastern part of the trough, whereas fresh waters occur in the southern part of the trough. Water mineralisation across the area of the Mogilno-Łódź Trough ranges from 0.2 up to $100.8 \mathrm{~g} / \mathrm{dm}^{3}$ (Górecki et al., 2010; Sowiżdżał et al., 2017).

Poddębice is located in the Polish Lowlands, and thus in area with good borehole control and relatively predictable geological structure. Furthermore, a geothermal plant in Uniejów, producing geothermal water from Lower Cretaceous sandstones at 1.9-2.1 km below ground level, is located nearby. Water with the temperature of up to $68^{\circ} \mathrm{C}$ and output of $120 \mathrm{~m}^{3} / \mathrm{h}$, with maximum drawdown of $26 \mathrm{~m}$, is characterized by mineralisation of $\sim 6-8 \mathrm{~g} / \mathrm{dm}^{3}$. As the result of water flow in the level operated, the well's supply derives most probably from the east and the south-east. Within the area of supply, the water flow is from the Lower Cretaceous outcrop to the direction of the water intake. Water supply derived from the overlying Upper Cretaceous aquifer is not excluded; it remains negligibly low. The mineralisation of the Lower Cretaceous water increases sharply to the north-west, i.e. to the area of the Uniejów 1 well where the general TDS totals $21.9 \mathrm{~g} / \mathrm{dm}^{3}$ (Fig. 6). This phenomenon may be related to the elevation of the Lower Cretaceous succession between Poddębice and the Uniejów 1 well, resulting in the accumulation of dense groundwaters high in TDS in the vicinity of the latter which, due to the structural elevation (barrier) does not flow down towards Poddębice, or towards the town of Uniejow as the mineralisation of exploited water, of sodium chloride type, varies between $6.7-8.8 \mathrm{~g} / \mathrm{dm}^{3}$.

Based on regional hydrogeological analysis of the Poddębice area, the recharge area of the Lower Cretaceous aquifer is most likely located in the east, and is associated with sub-Cenozoic subcrops of Lower Cretaceous strata around Łódź, $\sim 15 \mathrm{~km}$ east of the Poddębice GT-2 borehole. 
In realising a geothermal project, an important step is the quantification of the geological risk values (Schumacher et al. 2020); however, in some situations risk assessment is difficult, as examples from Poddębice and Wiśniowa show.

\section{CONCLUSIONS}

Increasing energy prices and poor air quality in many regions of Poland is the main reason for focus on alternative energy sources for heating. For many regions of Poland, a solution that can bring significant environmental benefits is the efficient development of geothermal resources. The best geothermal conditions in Poland occur in the area of the Polish Lowlands and Podhale (Inner Carpathians). At Podhale, geothermal water intakes with high yield and of high water temperature have been used for 25 years for heating. In the Polish Lowland the best geothermal prospects relate to Lower Jurassic and Lower Cretaceous successions. Waters in those reservoirs are characterized by favourable temperatures (reaching $>90^{\circ} \mathrm{C}$ ) and high borehole outputs (up to several hundred $\mathrm{m}^{3} / \mathrm{h}$ ).

The hydrogeothermal conditions occurring in geothermal regions are constant, though knowledge of them may change for instance, by drilling of a new exploratory borehole, conducting additional laboratory tests, geophysical exploration, etc. In some cases, in areas of complex geological structure or in places with scarce availability of geological information, as in the Carpathians, determination of hydrogeothermal parameters is difficult. In areas with less complex geological structure (e.g the Polish Lowland), estimation of hydrogeothermal conditions is more precise, which translates into a lower geological risk for potential investors, although there are cases of overestimation or underestimation of geothermal resources. The results of geological studies are sometimes surprising, as it is not everywhere possible to fully predict the effects of drilling boreholes. This pertains most to areas of complex geological structure, although, in some cases, the parameters of waters exploited in areas of presumed predictable geology are astonishing.

The Polish Lowlands include, inter alia, a geothermal plant in Poddębice, from which fresh waters are produced from a Lower Cretaceous reservoir. This phenomenon of particularly low TDS $\left(0.4 \mathrm{~g} / \mathrm{dm}^{3}\right)$ has been researched, due to proximity of
Uniejów, where waters with much higher mineralisation have been exploited from the same reservoir for many years. The mineralisation value of the Lower Cretaceous waters increases sharply to the north-west, i.e. in the area of the Uniejow 1 well where it totals to $21.9 \mathrm{~g} / \mathrm{dm}^{3}$. This phenomenon may reflect the elevation of the Lower Cretaceous succession between Poddębice and the Uniejów 1 well area, resulting in the accumulation of dense groundwaters high in TDS in the vicinity of the latter, which due to the structural elevation (barrier) does not flow down towards Poddębice town, or towards Uniejow as the mineralisation of exploited water there varies between $6.7-8.8 \mathrm{~g} / \mathrm{dm}^{3}$, of sodium chloride type.

Before the Poddebice GT-2 well was drilled, it was thought impossible to predict such a value of geothermal water mineralization. In this case, the results were very positive, because the low mineralisation of the geothermal water creates more opportunities for its use. However, geological risk means that geothermal parameters can also be overestimated.

The Outer Carpathians and the Carpathian Foredeep, due to their complex geological structure, are characterized by a considerably lower geothermal potential resulting mainly from lower potential water output. However, local analyses suggest that in some regions there is a chance of providing waters of suitable temperature and output, for example near Wiśniowa, where during drilling for hydrocarbons a sudden brine outflow occurred with an output of $180 \mathrm{~m}^{3} / \mathrm{h}$ and a temperature of $85^{\circ} \mathrm{C}$. This does not clearly demonstrate a geothermal potential for the region, but rather three different scenarios of geothermal reservoir management, dependent upon the acquired hydrogeothermal reservoir parameters. These scenarios will be tested in the near future when a geothermal borehole will be drilled to constrain the hydrogeothermal parameters and the local geothermal potential.

In geothermal exploration, as in analogous subsurface industries, uncertainty is likely to have the most significant effect on the final interpretation of the most important geothermal factors, i.e., temperature and water flow rate.

Acknowledgments. The paper was prepared as a result of AGH-UST statutory research grant No. 16.16.140.315. Special thanks are due to the reviewers for substantive comments, which improved the quality of this article.

\section{REFERENCES}

Bond, C.E., 2015. Uncertainty in structural interpretation: lessons to be learnt. Journal of Structural Geology, 74: 185-200.

Bujakowski, W., Tomaszewska, B., Pająk, L., Kaczmarek, R. Borsukiewicz-Gozdur, A., Mazurek, R., Wiśniewski, S., Nowak, W., Miecznik, M., Barbacki, A., Bielec., B., Skrzypczak, R., Operacz, T., Freiwald, P., Kujawa, T., Stachel, A.A., Sowiżdżał, A., Górecki, W., Papiernik, B., Hajto., M., Ciężkowski, W., Kępińska, B., Chowaniec, J., Czerwińska, B., Franus, W., Hołojuch, G., Kasztelewicz, A., Leśniak, G., Przelaskowska, A., 2014. Atlas of the possible use of geothermal waters for combined production of electricity and heat using binary system in Poland. MEERI PAS, Kraków.

Chowaniec, J., 2009. Hydrogeology study of the western part of the Polish Carpathians (in Polish with English summary). Biuletyn Państwowego Instytutu Geologicznego, 434: 1-98.

Ciężkowski, W., 2011. Kierunki rozwoju i możliwości wykorzystania geotermii głębokiej na Dolnym Śląsku (in Polish). In: Strategia rozwoju energetyki na Dolnym Śląsku na podstawie metody foresightowej Delphi (eds. E. Ropuszyńskiej-Surmy and Z Szalbierza). Oficyna Wydawnicza Politechniki Wrocławskiej Wrocław.
Dadlez, R., Kowalczewski, Z., Znosko, J., 1994. Some key problems of the pre-Permian tectonics of Poland. Geological Quarterly, 38 (2): 169-190.

Dadlez, R., Marek, S., Pokorski, J., 2000. Mapa geologiczna Polski bez utworów kenozoiku, w skali 1:1 000000 (in Polish). Państwowy Instytut Geologiczny, Warszawa.

Dowgiałło, J., 2002. The Sudetic geothermal region of Poland. Geothermics, 31: 343-359.

Dubrule, O., 2003. Geostatistics for Seismic Data Integration in Earth Models. 2003 Distinguished Instructor Short Course. Distinguished Instructor Series. No. SEG/EAGE. Tulsa, Oklahoma, USA.

Fistek, J., 1989. Rola uskoku Pstrążna-Gorzanów w kształtowaniu warunków hydrogeologicznych SW obrzeżenia synklinorium śródsudeckiego (in Polish). Prace Naukowe Instytutu Geotechniki Politechniki Wrocławskiej, 58: 361-368.

Górecki, W., Hajto, M., Strzetelski, W., Szczepański, W., 2010. Lower Cretaceous and Lower Jurassic aquifers in the Polish Lowlands (in Polish with English summary). Przegląd Geologiczny, 58: 589-593. 
Górecki, W., (ed.), Sowiżdżał, A., Jasnos, J., Papiernik, B., Hajto, M., Machowski, G., Kępińska, B., Czopek, B., Kuźniak, T., Kotyza, J., Luboń, W, Pełka, G., Zając, A., Szczepański, A., Haładus, A., Kania, J., Banaś, J., Solarski, W., Mazurkiewicz, B., Zubrzycki, A., Luboń, K., Peryt, T., Barbacki, A., Pająk, L., Tomaszewska, B., Harasimiuk, M., Kurzydłowski, K., Nowak, J., Latour, T., Czerwińska, B., Kudrewicz, R., Szewczyk, J., 2012. Geothermal Atlas of the Carpathian Foredeep. AGH-UST, Kraków.

Górecki, W., (ed.), Hajto, M., Augustyńska, J., Jasnos, J. Kuśmierek, J., Kuźniak, T., Machowski, G., Machowski, W. Nosal, J., Michna, M., Papiernik, B., Sowiżdżał, A., Stefaniuk, M., Szczygieł, M., Wachowicz-Pyzik, A., Zabek, G., Rajchel, L., Lemberger, M., Czop, M., Haładus, A., Kania, J., Szczepański, A., Golonka, J., Banaś, J., Mazurkiewicz, B., Solarski, W., Capik, M., Porowski, A., Oszczypko, N., Ostrowski, C., Targosz, P., Wojdyła, M., Barbacki, A., Bielec B., Bujakowski, W., Hołojuch, G., Kasztelewicz, A. Kępińska, B., Miecznik, M., Pająk, L., Skrzypczak, R., Tomaszewska, B., Budzisz, P., Zastrzeżyńska, J., Herman, Z., Harasimiuk, M., Czerwińska, B., Kubik, B., Pasek, P., Paliychuk, U., Chowaniec, J., Szewczyk, J., Baran, U., Kudrewicz, R., Borsukiewicz-Gozdur, A., Nowak, W. Wiśniewski, S., Kurzydłowski, K., J., Kalandyk, K., 2013. Geothermal Atlas of the Eastern Carpathians. AGH KSE, Kraków.

Górecki, W., Sowiżdżał, A., Hajto, M., Kotyza, J., 2015a. Ocena możliwości pozyskania i wykorzystania wód termalnych w rejonie Wiśniowej, projekt zrealizowany na zlecenie Urzędu Gminy Wiśniowa (in Polish). Archiwum AGH KSE.

Górecki, W., Sowiżdżał, A., Hajto, M., Wachowicz-Pyzik, A., 2015b. Atlases of geothermal waters and energy resources in Poland. Environmental Earth Sciences, 74: 7487-7495.

Hajto, M., 2011. Geothermal potential of the Outer Western Carpathians (in Polish with English summary). Technika Poszukiwań Geologicznych, Geotermia, Zrównoważony Rozwój, 50: 37-49.

Journal of Laws, 605, 2006. Rozporzadzenie MINISTRA ZDROWIA, z dnia 13 kwietnia 2006 r. Dz.U. Poz.605 wraz z późniejszymi zmianami w sprawie zakresu badań niezbędnych do ustalenia właściwości leczniczych naturalnych surowców leczniczych i właściwości leczniczych klimatu, kryteriów ich oceny oraz wzoru świadectwa potwierdzającego te właściwości (in Polish).

Kępińska, B., 2019. Geothermal Energy Use - Country Update for Poland, 2016-2018; European Geothermal Congress 2019, Den Haag, The Netherlands, 11-14 June 2019.

Kępińska, B., Barbacki, A.P., Bielec, B., Bujakowski, W., Dendys, M., Hołojuch, G., Galos, K., Kasztelewicz, A., Kęsek, W., Lankof, L., Miecznik, M., Pająk, L., Skrzypczak, R., Tomaszewska, B., Stefaniuk, M., Cygal, A., Hajto, M. Hałaj, E., Królikowski, M., Mitan, K., Ostrowski, C., Papiernik, B., Sada, M., Sowiżdżał, A., Wiśniowski, R., Nagy, S., Sapińska-Śliwa, A., Śliwa, T., Kiełczawa, B., Liber-Makowska, E., Blachowski, J., Midttømme, K., Dar, U.L. , Aall, Ø.K., Birkeland, A., Gannefors Krafft, Ch., Henne, I., Kocbach, J., Ramstad, R. K., Skauge, J.B., Stavland, S.H., Talhaug, E.S., Petursson, B., Einarsson, F.Ó.P., Danielsson, H.F.K., Tulinius, H., Gałeczka, I., Geirsson, K., Björnsson, J., Björnsson, S., Friōleifsson, S.I., Guđmundsson, B., Guđmundsson, J.R., Guđmundsdóttir, M., Hjaltason, S.E., Ketilsson, J., Torvaldsson, J.Á.H. , Sighvats T.E. , Dumas, P., Garabetian, T., Pinzuti, V., Brzyszcz, H., Krygier, P., Turkowski S., Kaczmarczyk, R., Szczygieł, G., Sęczkowski, P., Srogosz, M., Osiecki, P., Dobrowolski, D., Balcer, M., Bociek, Z., Jankowski, S., Karska, A., Ogórek, A., Peraj, A., 2017. Geothermal energy - a basis for low-emission space heating improving living conditions and sustainable development - preliminary studies for selected areas in Poland Study Visits. Report. http://www.eeagrants.agh.edu.pl/wp-content/uploads/2017/12/EEA-SV Report_GeoHeatPol-2017.pdf

Kulma, R., 1995. Podstawy obliczeń filtracji wód podziemnych (in Polish). Wydawnictwa AGH, Kraków.
Lindal, B., 1973. Industrial and Other Application of Geothermal Energy. Armstead, H.C.H., Geothermal Energy, UNESCO, Paris: 135-148.

Machowski, W., Machowski, G., Białecka, K., 2013. Ocena możliwości pracy dubletu geotermalnego na strukturze Wiśniowej koło Strzyżowa, jako wynik modelowań dynamicznych (in Polish). Technika Poszukiwań Geologicznych, Geotermia, Zrównoważony Rozwój, 2: 95-104.

Nian, Y.-L., Cheng, W.-L., 2018. Insights into geothermal utilization of abandoned oil and gas wells. Renewable and Sustainable Energy Reviews, 87: 44-60.

Oszczypko, N., Ślączka, A., Żytko, K., 2008. Tectonic subdivision of Poland: Polish Outer Carpathians and their foredeep (in Polish with English summary). Przegląd Geologiczny, 56: 927-935.

Paczyński, B., Płochniewski, Z., 1996. Wody mineralne i lecznicze Polski (in Polish). PIG, Warszawa.

Plewa, S., 1994a. Parametry geotermalne na obszarze Polski (in Polish). Wyd. CPPGSMiE PAN, Kraków.

Plewa, S., 1994b. Rozkład parametrów geotermalnych na obszarze Polski (in Polish). Wyd. CPPGSMiE PAN.

Plezia, B., 1992. Dokumentacja wynikowa odwiertu poszukiwawczego Wiśniowa-1 (in Polish). Archiwum PGNiG S.A., Jasło.

Ponikowska, I., 1995. Medycyna uzdrowiskowa w zarysie (in Polish). WATEXTS, Warszawa.

Ponikowska, I., 2002. Kompendium balneologii (in Polish). Wydawnictwo Adam Marszałek.

Ponikowska, I., Ferson, D., 2009. Nowoczesna medycyna uzdrowiskowa (in Polish). Medi Press, Warszawa.

Posyniak, A., 2015. Dodatek $\mathrm{nr} 1$ do „Dokumentacji hydrogeologicznej ustalającej zasoby eksploatacyjne ujęcia wód termalnych „Poddębice GT-2" z utworów kredy dolnej w miejscowości Poddębice”. Arch. Geotermia Poddębice Sp. z o.o., Warszawa.

Schumacher, S., Pierau, R., Wirth, W., 2020. Probability of success studies for geothermal projects in clastic reservoirs: from subsurface data to geological risk analysis. Geothermics, 83: 101-725.

Sowiżdżał, A., 2016. Possibilities of petrogeothermal energy resources utilization in central part of Poland. Applied Ecology and Environmental Research, 14: 555-574.

Sowiżdżał, A., 2018. Geothermal energy resources in Poland overview of the current state of knowledge. Renewable and Sustainable Energy Reviews; 82: 4020-4027.

Sowiżdżał, A., Papiernik, B., Machowski, G., Hajto, M., 2013. Characterization of petrophysical parameters of the Lower Triassic deposits in prospective location for Enhanced Geothermal System (central Poland). Geological Quarterly, 57 (4): 729-743.

Sowiżdżał, A., Hajto, M., Papiernik, B., Mitan, K., Hałaj, E., 2017. Possibilities of geothermal sector development in central Poland in reference to extended structural and parametrical analysis of Mogilno-Łódź Trough.Geological Exploration Technology, Geothermal Energy, Sustainable Development, 56: 17-31.

Tadych, J., Rasała, M., Tadych, A., 2010. Dokumentacja hydrogeologiczna ustalająca zasoby eksploatacyjne ujęcia wód termalnych „Poddębice GT-2" w miejscowości Poddębice (in Polish). Thermhouse. 2010. Arch. Geotermia Poddębice Sp. z o.o., Inowrocław.

Westphal, D., Weijermars, R., 2018. Economic appraisal and scoping of geothermal energy extraction projects using depleted hydrocarbon wells. Energy Strategy Reviews, 22: 348-364.

Wiktorowicz, B., 2014. Wody termalne niecki łódzkiej - zielona energia z wnętrza Ziemi (in Polish). PIG-PIB, Warszawa.

Witter, J.B., Trainor-Guitton, J.W., Siler, D.L., 2019. Uncertainty and risk evaluation during the exploration stage of geothermal development: a review. Geothermics, 78: 233-242.

Wójcicki, A., Sowiżdżał, A., Bujakowski, W. (eds.), 2013. Ocena potencjału, bilansu cieplnego i perspektywicznych struktur geologicznych dla potrzeb zamkniętych systemów geotermicznych (Hot Dry Rocks) w Polsce (in Polish). Ministerstwo Środowiska, Warszawa/Kraków. 